\title{
Distinctive Features of the Usage of Argumentative Strategies and Techniques in Political Discourse (on the Materials of French and Georgian Languages)
}

\author{
Kristina Adeishvili \\ Faculty of Arts and Sciences, Ilia State University, Tbilisi, Georgia
}

\begin{abstract}
In our article we have studied the argumentation phenomenon as one of the basic branches of the communicative linguistics. Namely, we have researched particular features of usage of argumentative strategies and techniques in Georgian and French political discourses. The research was performed on the discourses enunciated by the former president of France - Nikolas Sarkozy and the president of Georgia Mikheil Saakashvili in the electoral campaign before the wide audience for persuading of the electorate where we have analyzed by means of the comparative methodology the argumentative strategies and techniques most clearly expressing the argumentative specification of their discourses. These are: value argument, authority argument, parallel syntax constructions, strategy of the personality identifying, metaphor, strategy aimed at different orientations. We have also tried to determine the impact of different socio-cultural environment on the construction of argumentative discourse in terms of choice of argumentative strategies and techniques.
\end{abstract}

Index Terms -communicative linguistics, argumentation, argumentative strategies, argumentative techniques, political discourse

\section{INTRODUCTION}

In this article we aimed at researching of distinctive features of the usage of the argumentative strategies and techniques in French and Georgian political discourse. For this we will try to determine the impact of different sociocultural environment on the construction of argumentative discourse in terms of choice of argumentative strategies and techniques.

We have chosen political discourses as a research corpus, in particular the discourses said by the former president of France - Nikolas Sarkozy and the president of Georgia - Mikheil Saakashvili in the electoral campaign before the wide audience for persuading of the electorate.

The development of our research is stipulated by the determination of the specifications of argumentative strategies and techniques of Saakashvili's and Sarkozy's discourses with the use of comparative methodologies, as well by the analyses of the impact of fully different from each other French and Georgian socio-cultural environment by structuring of the argumentative discourses.

Argumentation is a very complex phenomenon. It is studied from different aspects by such sciences as logics, political science, social studies, sociolinguistics, psychology. We will study the argumentative phenomena as subject of study of argumentation theory of one of the basic branch of communicative linguistics. Herewith, we note that the argumentation is an art of persuasion for modern communicative linguistics.

Political discourse as well the argumentations phenomena is an interdisciplinary research subject. A number of humanitarian scientists: politics, social studies, theory of communication, sociolinguistics, psychology, linguistics, theories of argumentation study it from different aspects. We will analyze the political discourse from the point of view of argumentative strategies and techniques used in it.

\section{LITERATURE REVIEW}

As it is well known, the argumentation phenomena became a focus of attention of the scientists very early, in the $5^{\text {th }}$ century B.C.

From the formation until now the argumentation theories have passed three basic stages of development:

1. The founder of the argumentation theories is considered Greek scientist Aristotle. In his work "Rhetoric" he worked out the following main conception of oratory: "The method of eloquence is a method of persuasion, persuasion is some kind of substantiation, that's why be believe most of all in what we consider substantiated" (Aristotle, 1981, p. 33).

2. In the 16th century in the period of Renaissance the rhetoric suffered some kind of discrediting. In this period the antique conception of rhetoric gradually changed the approach with the rhetoric as an art of good sayings. 
3. From the second half of the $20^{\text {th }}$ century the third stage, stage of changes of the argumentation theory has begun. In 1958 Chaïm Perelman with Lucie Olbrechts-Tyteca published their work "The New Rhetoric: A Treatise on Argumentation" fully restoring the basic conceptions of antique rhetoric. In the work the authors formalized the modern approach towards the argumentation which our research is based on as follows: "Argumentation aims at securing the adherence of those to whom it is addressed, it is, in its entirety, relative to the audience to be influenced" (Perelman, 2000, p. 5). After publishing of the Perelman's work the argumentation theories have been shifted at the new stage of development where the argumentation phenomena is worked out by different approach. Important works on argumentation were created by: Oswald Ducrot "Dire et ne pas dire" 1972, Jacques Moeschler "Argumentation et conversation" 1985, Christian Plantin "Essais sur l'Argumentation"1990, Jean-Blaise Grise "Logique et language" 1990, Bernard Meyer "Maitriser l'argumentation" 1990, Ruth Amossy “Argumentation dans le discours" 2000 etc.

Anscombre and Ducrot considered the argumentation as a belonging to language and not to discourse. According to this theory the argumentation as a chain of statements directing towards the conclusion and the argumentative power is set in the meaning of the statement. "The meaning for the statement means the orientation" (Anscombre, 1988, introduction).

In his work "Argumentation et conversation" Moeschler has integrated the theories of Anscombre and Ducrot in the conversation analysis. "Each verbal interaction performing in the conversation determines the frame of argumentation and interaction" (Moeschler, 1985, p. 14).

Jean-Blaise Grise regards the argumentation in the frames of natural logics. According his explanation "The argumentation considers the listener not as manipulation object but as Alter Ego on which it impacts to share its consideration. The impact on the listener means try to change his different conception on the subject by putting to the fore of definite aspects, by hiding of definite aspects, by providing of new information" (Grise, 1990, p. 41).

According to Amossy's definition "Argumentation studies the effectiveness of discourse in cultural, social and institutional environment” (Amossy, 1990, p. 146).

As for political discourse, during our research we will base on the definition suggested by Charaudeau: "Political discourse as a communicative act directly relates the persons participating in the political communication act, the aim of whose is to impact on the views of members of this act to win over them, to refuse them or to reach the consensus" (Charaudeau, 2005, p. 24).

Selection of electoral discourses of the president candidates as a corpus is very interested for the purposes of our research from the point of view that the argumentativity of political discourse has a particular importance during the electoral campaign. The discourse said by the candidate should be so effective that he would be able to persuade in his preference not only numerous and various electors all over the country but involvement of the recipient expressing in the going to precinct on the elections day and voting in his favor.

\section{METHOD}

As the research corpus we have chosen the discourses of Nikolas Sarkozy, the Presidential Candidate of presidential elections of France in 2007 and Mikheil Saakashvili, the Candidate of the presidential elections of Georgia in 2008. Georgian corpus we have found on the official web site of the President of Georgia www.president.gov.ge, and French corpus - on the official web site of the President of France www.elisee.fr. As Charaudeau stated, today the scientists research the political discourse by the combination of different methods. E.g. lexicometric analysis means the corpus research from the statistical point of view and as well the analysis of the persons' positions participating in its semantics and political communicative act. Enunciative analysis studies locution behavior of the persons involving in the political communicative act and their political ideological positions.Argumentative analysis studies the logic of reasoning characterizing a politician of a certain political position (Charaudeau, 2005). At the first stage we have separately analyzed the discourses of French and Georgian candidates on which we performed the argumentative and lexicometric analysis and emphasized the argumentative strategies and techniques characterized in the discourse of the French candidate and in the discourse of the Georgian candidate separately, and determine the frequency of use and the actuality of certain argumentative strategies and techniques in the discourse of a certain candidate. After this in our article based on the comparative methodology we have analyzed the distinctive similarities and differences between their discourses from this point of view.

\section{RESULTS}

In his work Charaudeau analyzes the main argumentative strategy of the political discourse - strategy of persuasion in which the scientist distinguishes so-called sub-strategies of different branches: strategies of the person identifying, creation of the personal identity - ethos as a mirror of person, mutually opposite and changeable face, issue of discourse dramatization, disqualification of the opponent, issue of values selection, issue of the value presentation for the recipient, strategy aimed at different orientations etc (Charaudeau, 2005). For the performance of these strategies the argumentator uses the argumentative techniques the detailed analysis of which Perelman suggests in his work. The argumentative techniques reviewed by Perelman are as follows: contradiction and incompatibility, identity and determination, analysis and tautology, the rules of justice, reciprocity argument, transitivity argument, dividing the 
whole into parts, comparison argument, reasons, person and his acts, act-person relationship, authority argument, value argument, discourse as an orator's act, group and group members, symbols, example, model and anti-model, perfect creation as a model, analogy, metaphor etc (Perelman, 2008).

At this stage we will try to analyze several argumentative strategies and techniques chose by us and more clearly identifying the argumentativity specific of discourses enunciated by Saakashvili and Sarkozy. These are: value argument, authority argument, parallel syntax constructions, strategy of the personality identifying, metaphor, strategy aimed at different orientations.

We begin the corpus research by determining of common argumentative strategies and techniques which are actively used by both politicians in their discourses. However, the dosing of baseline strategies and techniques revealed by us in discourse of both languages more or less differs from each other and we will pay an attention at these differences.

In French and Georgian discourses value argument has differentiated as one of the basic argumentative techniques. As Charaudaeu stated the usage of values requires great care from the politician because among a lot of values he has to select the values that would effectively impact on the audience and herewith to present them correctly (Charaudeau, 2005). In the discourse chose by us both candidates are trying to use the words expressing such ideas that are common values for the society. By this technique the candidates make ideologization of their discourse and try to create positive relation for the listener towards the argumentator. In their discourses there are lots of arguments expressing both concrete values and abstract ones as well. The research reveals that Saakashvili pays a particular attention to the word "Democracy" the reason of which is that in Georgia the democratic structures have not established yet in the manner as in the developed countries - including - France. That's why Sarkozy does not consider it necessary to emphasize this specific value in the dosage that Saakashvili does. However one may distinguish from the words expressing the values in Sarkozy's discourse the word "France" that the candidate uses more frequently that Saakashvili uses the word "Georgia". Thus, in the discourse orientated for French audience the most important value is France. In Sarkozy's discourse France is an ideal, and in the discourse of Georgian politician the Democracy is the goal.

Here are several examples from the politicians' discourses:

Sarkozy:

La France, elle a le visage, l'âge, la voix de tous ceux qui ont cru en elle, qui se sont battus pour elle, pour son idéal, pour ses valeurs, pour sa liberté.

"France, it has face, age, vote of all of those who believes in it, who has fought for it, its ideals, its values, its liberty." Nous devons changer radicalement nos comportements pour aller vers davantage d'impartialité, d'équité, d'honnêteté, de responsabilité, de transparence.

"We should change our behavior radically to be closer to impartiality, equality, honesty, responsibility, transparency."

Saakashvili:

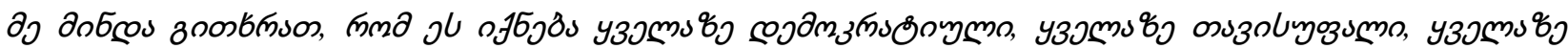

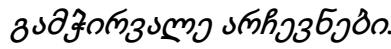

"I would like to tell you that it will be the most democratic, the most free, the most transparent elections."

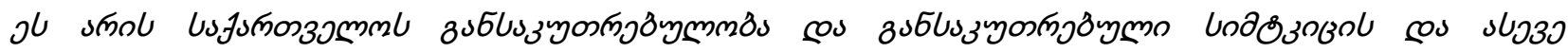

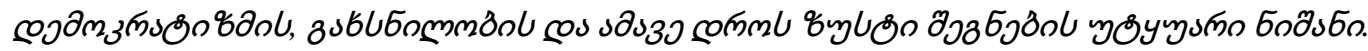

"This is Georgia's uniqueness and a reliable sign of especial strength and democracy, openness and exact understanding as well."

During comparing of French and Georgian discourses it was clearly stood out the argumentative "method" characterizing both candidates as Aristotle calls it (Aristotle, 1981, p. 193). Sarkozy's address is almost fully constructed by parallel syntax constructions that affix a special sonority and emotionality to this discourse. In parallel syntax constructions the French candidate uses and repeats the words expressing such values as: France, Republic, Democracy. It should be noted that from the beginning Sarkozy uses theses words with definite article and after repeating several times he substitutes the definite article with possessive adjectives. With this he tries to underline his own personality. At the same time expression of the ethos in his discourse in such manner is aimed at the influence on the listener. Let's give some examples:

Ma France c'est le pays qui a fait la synthèse entre l'ancien Régime et la Révolution, entre l'Etat capetién et l'Etat républician, qui a inventé la laïcité pour faire vivre ensemble ceux qui croient au Ciel et ceux qui n'y croient pas.

"My France is a country that performed the synthesis of the old regime and the revolution, republican State and CapetiansState, that created laïcité, so that those who believe in religion and those who do not believe may live together."

Ma France c'est le pays qui entre le drapeau blanc et le drapeau rouge a choisi le drapeau tricolore, en a fait le drapeau de la liberté et l'a couvert de gloire.

"My France is a country that chose tricolor flag between red and white flags and created from it the Flag of Liberty and made it positive." 
In Sarkozy's discourse he repeats the most frequently the parallel syntax construction beginning as follows: Je veux être le Président..."I am willing to be a President..."

Je veux être le Président qui s'efforcera de maraliser le capitalisme.... Je veux être le président qui va remettre la morale au coeur de la politique.

"I am willing to be a President who will try to moralize the capitalism... I am willing to be a President who will bring the moral into the center of politics."

One of the highlighted argumentative techniques is considered the parallel syntax constructions in the Saakashvili's discourse as well. However, Sarkozy's basing on this argumentative technique with similar intensity is not determined in the Georgian politician's discourse.

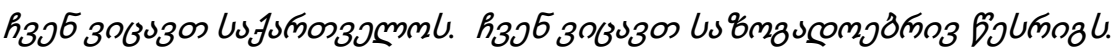

"We defend Georgia. We defend public order."

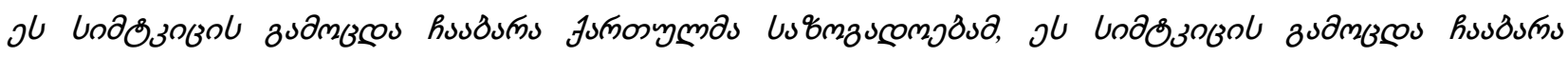

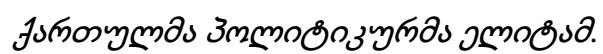

"Georgian society has passed the examination of stability. Georgian political elite has passed the examination of stability."

Actuality of the above argumentative technique is stipulated by the fact that a listener remembers easier these parts of discourse due their repeating for several times and makes it more emotional. In the discourse for Georgian electorate it would no be so effective the usage of the parallel syntax constructions in the dosage as it is used in the French discourse because the Georgian electors are faced against lots of socio-economic problems. They are waiting for concrete suggestions regarding the concrete problems and the constructing of the parallel syntax constructions for their conveying as in the French discourse would be excessive. However as we have noted this argumentative technique in the discourse of both languages is actual.

In the discourse of both candidates it also used the authority argument. Perelman gives us the following definition of the above argumentative technique: “The authority argument uses the human deeds and ideas and people's group deeds and ideas as the means of proving of his thesis" (Perelman, 2008, p. 411). French and Georgian candidates cite the competent and authoritative persons well-known to the general public, trying their ideas for strengthening of their own positions.

While talking about the consolidation and renovation of France Sarkozy uses Pompidou's words:

Après mais 1968 Georges Pompidou avait dit: "Le monde a besoin d'une nouvelle Renaissance."

"After May of 1968 Georges Pompidou declared: The word needs a new Renaissance."

Sarkozy calls on the electors for actions and movements and for conveying uses Camus's words:

Face au drame algérien, Camus avait dit: "Les grandes tragédies de l'histoire fascinent souvent les hommes par leurs visages horribles. Ils restent alors immobiles devant elles sans pouvoir se décider à rien qu'à attendre."

Attendre quoi? Sinon le pire?

Il avait ajouté: "La force du cœur, l'intelligence, le courage suffisent pourtant pour faire échec au destin."

"Camus said about the Algerian crisis:"The great tragedies of the history often make people stare with their terrible faces, at that moment they stop and cannot do anything but to wait."

What should one wait for if not the worth things?

He added: "The power of heart, intellect and braveness are sufficient for defeating the failure."

As for Saakashvili he rarely cites. But in his discourse as well in Sarkozy's discourse they often say only the names of the authoritative persona and authoritative organizations that serves for strengthening of the argumentative positions as well. The candidates try to show to the listener that they enjoy confidence among the reliable persons and with this they express the ethos; however in Sarkozy's discourse it has the appropriation of pathos by means of lexical units expressing parallel syntax constructions and emotion.

Sarkozy:

Je veux rendre hommage à Jacques Chaban-Delmas, général de la "Résistance" ... Son dernier grand combat politique fut pour moi le premier. J'avais 17 ans et l'impression de partir à la guerre ... Je veux rendre hommage à Achille Peretti, grand résistant, qui me confia mon premier mandat de conseiller municipal. Comme je veux dire mon amitié à Edouard Balladur qui m'a fait confiance en me donnant mes premières responsabilités ministérielles alors que j'étais si jeune encore. Je veux dire mon respect à Jacques CHIRAC qui en 1975 à Nice m'a offert mon premier discours.

"I would like to pay the tribute to the memory of Jacques Chaban-Delmas, the General of "Resistance"... His last great political struggle was the first for me. I was 17 then and I had a feeling that I was going to the war... I would like to pay the tribute to the memory of AchillePeretti, active member of "Resistance" who entrusted to me my first mandate of municipal voter. I would like so much to prove my friendship to Edouard Balladur, who confided in me and assumed on me the Minister's responsibility at such a young age. I would like to express my respect towards Jacques CHIRAC who yielded the word to me in 1975 in Nice."

Saakishvili: 


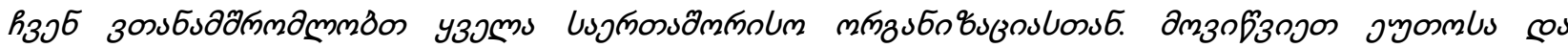

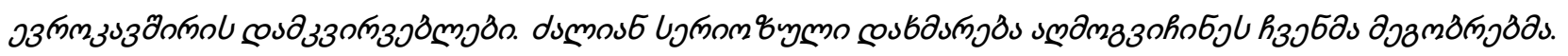

"We are cooperating with all international organizations. We have invited the OSCE and European observers. Our friends have rendered a very significant help to us. We have relations with Armenia, Azerbaijan, Turkey. They are our best friends."

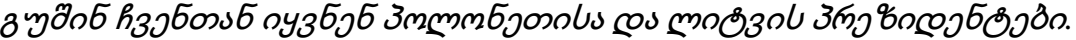

"Yesterday the presidents of Poland and Lithuania visited us."

As we can see authoritative persons are different for Georgian and French society. In the discourse for French audience only the names of French, high powered politicians and public persons are used as authorities and internationally recognized democratic institutes - sounds more persuading for Georgian electorate. In our opinion this tendency indicates at the different levels of democratic development of these two countries. The Georgian candidate needs to prove before the audience that in case of his coming in the government he will lead the country in the correct word of the democracy development meanwhile Sarkozy is a candidate for president of the country that is an authority from the point of view of the democracy development.

In political discourse it is very interesting the strategy of the person identifying analyzed in Charaudeau's work (Charaudeau, 2005). We will consider the specification of usage of person deictic of the singular and the plural the first and second person. With this linguistic method the argumentator can change implicitly the word referent. So called identifying formula "We" gives the opportunity of its identifying with the whole audience, and "Our" means the existence of possessive object common with the whole audience. Identifying formulas are necessary elements in the discourses of all candidates and they regularly resort to this rhetoric method to impact the audience. But from this point of view an important difference was identified in French and Georgian discourses. In Sarkozy's discourse the referent of "we" are French people in most cases, and in his discourse Saakashvili consider mainly his own political group as the referent of us.

Sarkozy:

Notre capacité à vivre ensemble à nous compendre et à respecter est notre bien le plus précieux.

"The most valuable our property is our ability to live together, to understand each other and to respect each other."

Tout ce qui affaiblit la France affablit chacun d'entre nous.

Everything that weakens France weakens each of us."

Saakashvili:

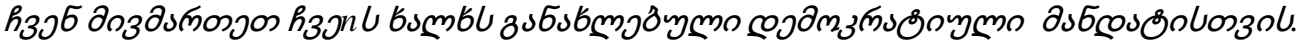

"We are addressing to our people for different democratic mandates."

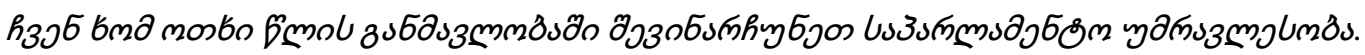

"We have managed to maintain a parliamentary majority for four years."

As for the deictic of the singular first person - "I", "My" - their number is quite numerous in the discourses of both languages. With these form the candidates emphasize on their own personalities and by means of ethos try to make a desirable impact. It should be noted one of the basic argumentative strategy of Sarkozy's address is an intensive usage of "I", "My". As we have noted while analyzing the parallel constructions Sarkozy's discourse is characterized by using of "my" with the words specifying the national values. No doubt that everyone protects its belonging. That's why Sarkozy tries to persuadethe listener that these values are really his. This is the purpose of intensive usage of possessive forms in his discourse. The research has shown to us that in Sarkozy's discourse "I" - "My" forms are much more numerous than "We" - "Our". Almost $77 \%$ of the first person deictic is of the singular and only $23 \%$ - in the plural (figure 1). In Saakashvili's discourse vice versa, deictic of the plural (65\%) prevails over the singular (35\%) (figure 2). In our opinion the technique chosen by Sarkozy ("I" - "My") clearly highlighting his own personality before the listeners would be ineffective before the Georgian listener in such a large dose. One of the characterized features of the ethno-culture of the Georgians is the subtle senses of individual pride, and French people are more characterized by the national honor, the feeling of honor that they are French.

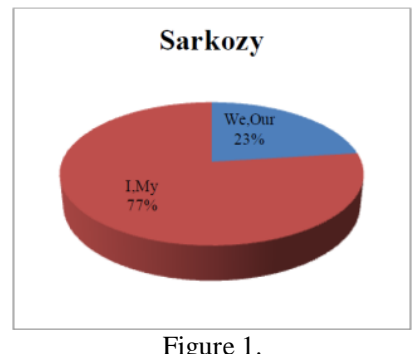

Figure 1. 


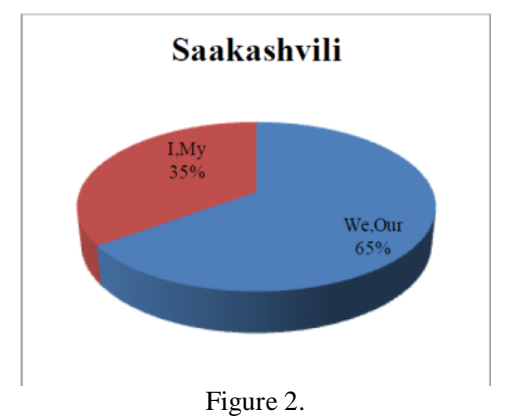

In his discourse Saakashvili intensively resorts to argumentative technique by using of metaphor. Perelman's metaphor is "reduced analogy received as a result of confluence of theme and phore" (Perelman, 2008, p. 535).

Perelman analyzes a "sleeping" metaphor as well (term used by Perelman, Perelman, 2008, p. 543). As we know the "sleeping" metaphor has not got a function of emotional impact. As if the metaphoric meaning has been erased in it because the perception of confrontation rarely occurs with direct and indirect meaning. In our research we will not focus at "sleeping" metaphor because its usage in political discourse is universal and a significant difference between the French and Georgian discourses has not been identified in our analysis.

It characterizes the author and the original metaphor is characterized by unexpectedness and rareness. It were the metaphors for emphasis impacting on the audience in the discourse for the Georgian electorate aimed at the impact on the listener.

Saakashvili:

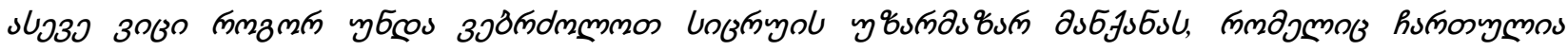

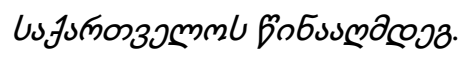

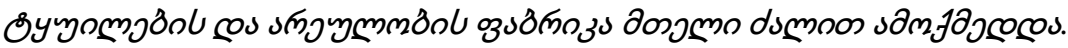

"Factory of lies and disorders was put in motion with the full power."

Sakozy rarely resorts to the metaphor potently impacting on the audience.

Our research has proved that Saakashvili uses the metaphor potently impacting on the audience to exacerbate the negative attitude of electorate towards the country's enemies, disturb the feeling of national issue among the electors which Georgia really faced with. Georgia is a small-scale country but geo-politically it is very important Caucasian country which has got independence for 20 years and is aspiring to the Euro-Atlantic structures integration. That's why it is not duly protected against the external threats; stable democratic institutes have not been established yet. Sarkozy's discourse is a carrier of positive charge and he does not consider it necessary to use the metaphors for similar purposes.

From the point of view of the strategies designated for the audience with different orientation the discourses of French and Georgian candidates for president differ from each other. As Perelman states: "The orator often has to persuade the composite audience that joints together people with different nature, function and aspirations. He has to use lot of arguments to win over the people with different thinking. In their discourse this is an art of foreseeing of people with different points of view characterizing great orators" (Perelman, 2008, p. 28).

Sarkozy's discourse is constructed in the manner that to be acceptable and likable for the amount of people as much as possible. In his discourse he pays a great attention to the adaptation with the individuals having any kind of political interest. French candidate tries to erase the ideological limit with the opposite parties and persuade the adherents of other political forces that they have got common values. With this he tries to win over the adherents of other candidates.

Ma France, c'est celle de tous ces Français qui ne savent pas très bien au fond s'ils sont de droite, de gauche ou du centre parce qu'ils sont avant tout de bonne volonté.

"My France is a country of all French people who do not know exactly if they are right-winger, left-winger or centrist because first of all they are the expressers of good will."

Je demande à mes amis qui m'ont accompagné jusqu'ici de me laisser libre, libre d'aller vers les autres, vers celui qui n'a jamais été mon ami, qui n'a jamais appartenu à notre camp, à notre famille politique qui parfois nous a combattu. Parce que lorsqu'il s'agit de la France, il n'y a plus de camp. Je demande à vous tous de comprendre que je ne serai pas que le candidat de l'UMP, qu'au moment même où vous m'avez choisi je dois me tourner vers tous les Français, quels que soient leur parcours, qu'ils soient de droite ou de gauche, de métropole ou d'Outre Mer, qu'ils vivent en France ou à l'étranger.

"I am asking my friends being with me so far to leave me free so that I reach others, to the people who had never been my friend, who had never been a member of my camp, my political family, who was sometimes fighting against us. Because when the case regards France the camps have no importance any more. Please, understand everybody that I will not only the UMP's candidate from the minute when you have elected me, I should return to each Frenchman whatever course they have, they are right-winger or left-winger, from metropolis or other countries, live in France or abroad." 
Sarkozy pays less attention to the criticism of opposite parties, their programs. And Saakashvili has chosen a different strategy towards the opposition. In his discourse he expresses absolutely negative relation towards them.

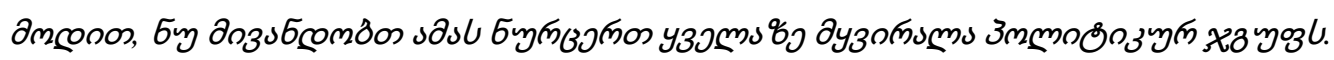

"Let's not to trust it to any most yelling political groups."

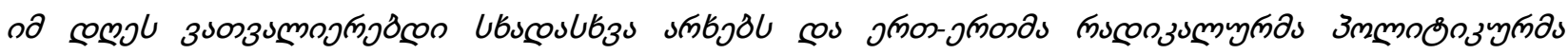

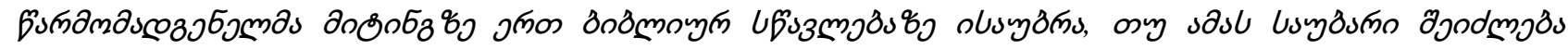
onfousl.

"On that day I was overlooking different channels and one of the radical political representatives was talking about one biblical teaching at the meeting if one may call it talk."

Sarkozy takes into account the diversity of French electorate with religious point of view; he tries to make an adaptation with electors with all kind of religion or atheists.

Opposer ce sentiment religieux à la morale lä̈que serait absurde. Nous sommes les héritiers de deux mille ans de chrétientéet d'un patrimoine de valeurs spirituelles que la morale laïque a incorporé. La laïcité à laquelle je crois, ce n'est pas le combat contre la religion. C'est le respect de toutes les religions.

"This religious feeling to opposite laïcité's moral would be absurd. We are the inheritors of two thousand-year Christianity and the spiritual values that the laïcité's moral had combined. Laïcité in which I believe is not a struggle between the religions but the respect towards all the religions."

And Saakashvili does not emphasize this question due to the fact that the majority of his electors are Orthodox Coreligionists despite the fact that Georgia is a country of a lot of ethnics and confessions.

\section{CONCLUSION}

Therefore, the results of the research conducted by us are as follows:

In the French candidate's discourse the leading argumentative strategies and techniques are: parallel syntax constructions, the deictic of the singular first person - I, argument value, aimed at different orientations.

In the Georgian candidate's discourse the leading argumentative strategies and techniques are: parallel construction, metaphor (author's, original), argument value, negative dependence towards the opposition.

In the discourses of French and Georgian candidates common basic argumentative strategies and techniques are: argument value, authority argument, parallel syntax construction.

The discourses we analyzed were successful for candidates. In 2007 Nikolas Sarkozy and in 2008 Mikheil Saakashvili won in the elections. And the elections of 2012 finished with loss for both candidates. (Saakashvili's party lost the parliamentary elections and Sarkozy - the presidential elections). For the following research we think it will be interested to analyze the discourses stated in the electoral campaign based on the argumentative techniques and to compare with the results of the analysis we have already conducted.

\section{REFERENCES}

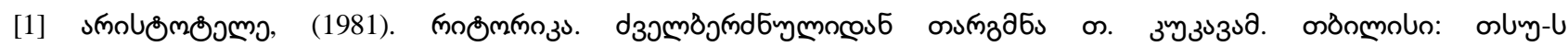

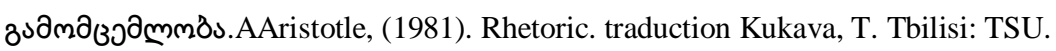

[2] Amossy, R. (2000). L'argumentation dans le discours. Paris: Nathan Université.

[3] Anscombre, J. C. \& O. Ducrot. (1988). L'argumentation dans la langue. Liège: Mardaga.

[4] Barth, E. M. \& J. L. Martens. (1982). Argumentation Approaches to Theory Formation. Amsterdam: John Benjamin.

[5] Besnard, P. \& A. Unter. (2008). Element of Argumentation. Cambridge: MIT Press.

[6] Blair, J. A. (2002). Crucial Concepts in Argumentation Theory. Argumentation and Advocay. 39. 1, 77-81.

[7] Blair, J. A. \& R. Jonson. (1987). Argumentation as dialectical Argumentation. Argumentation. 1. 1, 41-56.

[8] Blum-Kulka, S., J. House\& G. Kasper. (1989). Cross-Cultural Pragmatics: Requests and Apologies. Norwood: NJ: Ablex.

[9] Breton, P. (1996). L'argumentation dans la communication. Paris: La Découverte.

[10] Charaudeau, P. (2005). Le discours politique, Les masques du pouvoir. Paris: Vuibert.

[11] Charaudeau, P. \& D. Mainguaineau. (2002). Dictionnaire d'analyse du discours. Paris: Seuil.

[12] Dijk, T. V. (2006). Discourse and manipulation. Dicourse and society.17. 3, 359-383.

[13] Eemeren, V. (2002). Advances in Pragma-Dialectics, Amsterdam: SicSat; Newport News (Virginia), Vale Press.

[14] Grize, J. B. (1982). De la logique à l'Argumentation. Genéve: Droz.

[15] Labov, W. (1976). Sociolinguistique. Paris: Minuit.

[16] Meyer, M. (1996). Maitriser l'argumentation. Paris: A. Colin.

[17] Moeschler, J. (1985). Argumentation et conversation. Paris: Hatier.

[18] Perelman, C. \& O. Titeca. (2008). Traité de l'argumentation. La nouvelle rhétorique. Bruxelles: Edition de l’Université de Bruxelles.

[19] Perelman, C. \& O. Titeca. (2000). Traité de l'argumentation. La nouvelle rhétorique. Bruxelles: Edition de l'Université de Bruxelles.

[20] Plantin, C. (1990). Essais sur l'argumentation. Paris: Edition KIME.

[21] Wodak, R. (2009). The Discourse of Politics in Action. Politics as Usual. New York: Palgrave Macmillan. 
Kristina Adeishvili was born in Vani, Georgia, in 1982. Graduated from Ilia State University, she has M.A. degree in roman philology with distinction in 2007. From 2009 to 2010 she was Argumentation Theory and Enonciautive Theory teacher and researcher at Ilia State Universty. In 2012 she was in Paris-Est University (Paris, France) in the TEMPUS project for scientific research about her $\mathrm{PhD}$ thesis. Actually she is doctoral student in Ilia State University and is working on her PhD thesis about Argumentation in the political discourse. 